\title{
About role of adhesive and cohesive interactions in cement systems
}

\author{
Yu S Sarkisov ${ }^{1}$, I A Rahmanova ${ }^{1}$, N P Gorlenko ${ }^{1}$, D A Afanasyev ${ }^{1}$, \\ N O Solonicina ${ }^{1}$, N N Debelova ${ }^{1}$ and L F Ikonnikova ${ }^{2}$ \\ ${ }^{1}$ Tomsk State University of Architecture and Building, 2, Solyanaya sq., Tomsk, \\ 634003, Russia \\ ${ }^{2}$ Tomsk Polytechnic University, 30, Lenina ave., Tomsk, 634050, Russia \\ E-mail: ir9039508837@yandex.ru
}

\begin{abstract}
This work studies the effect on the strength and other mechanical characteristics of hardening structures in the "cement-water" system with a filler of identical chemical nature consisting of cement granules or cubes at different age and with their own characteristics. This study was performed in the light of a new paradigm in natural science and the unity and opposites of markovian and non-markovian processes with forming structures similar to own ones where the indicators are harmonic numbers, golden proportion and Fibonacci numbers. Moreover, structured modeling of the above mentioned systems was carried out, and effect of the ratio of adhesive and cohesive forces on the structure formation of cement systems was investigated. It was shown that it is necessary to have 238732 particles per $1 \mathrm{~m}$ of the sample, taking into account that the density of particles packing with a diameter of $1 \mathrm{~cm}$ is $100 \%$. If the density is lower, it is necessary to have 152788 particles. It was established that the strength of hardening structures depends on the age and configuration of filler granules.
\end{abstract}

\section{Introduction}

The problem associated with the creation of construction materials based on cement systems with the desired properties able to harden and accumulate strength under normal and extreme conditions is one of the most urgent in modern construction material science. It is known that some problems need further research [1]. These problems are as follows: the proportion of adhesive and cohesive contacts particles interaction accretion in cement systems, the variation of these ratio within the period of hydration of structure formation and finally the study of the role of adhesive-cohesive processes in cement systems and control methods of so called contact area in a conglomerate as the weakest part in the structure of cement systems [2-8]. The solution of these important problems is impossible without applying the achievements of fundamental science.

Nowadays there is a rapid progress of a new natural-scientific paradigm. In accordance to this new paradigm any processes taking place in the world should be considered as the unity and opposites of interaction of markovian and non-markovian processes [9-11]. It is inessential for markovian processes what happened to one or another component in the past, i.e. what impact or processing method this component has experienced during its existence or it is also not important what was the role of this component in the evolution process. Only the antecedent system status is of great importance for markovian processes. On the contrary, the memory of the past system status is vital for 
non-markovian processes. It is obvious that it is necessary to take into account the contribution of markovian and non-markovian processes to the evolution of the system. It is known that the indicators of these processes are the numbers of nature harmony, golden proportion and Fibonacci numbers [12, 13].

Widespread fractal structures [14] are the reflection of non-markovian processes and completely follow the interpretation with the involvement of Fibonacci numbers. Fractal structures are classified into several types as one of the ways of the origin and formation of similar structures under various conditions typical for natural and artificial materials [15].

This paper is concerned with so called fractal nested (embedded) structures [16] which ensure the maximum possible density of packing of the forming structure.

The purpose of this work is to determine the features of the progress of adhesive-cohesive processes in cement systems, including the contact area, and to perform structural modeling of hardening on the model of fractal nested (embedded) structures.

\section{Materials and methods}

To achieve the specified goal, structural modeling of the cement stone was carried out under the hypothesis of absolute homogeneity on mass, volume, density and configuration of all particles composing this structure. The computer simulation showed that the densest packing is obtained for absolute density (100\%) by the compulsory presence of 238732 particles per $1 \mathrm{~m}^{3}$ if assumed that all particles are ball-shaped and their diameter is 1 centimeter [17] (see Fig.1). If the density is 64\%, then 152788 particles per $1 \mathrm{~m}^{3}$ are required (see Fig.1)

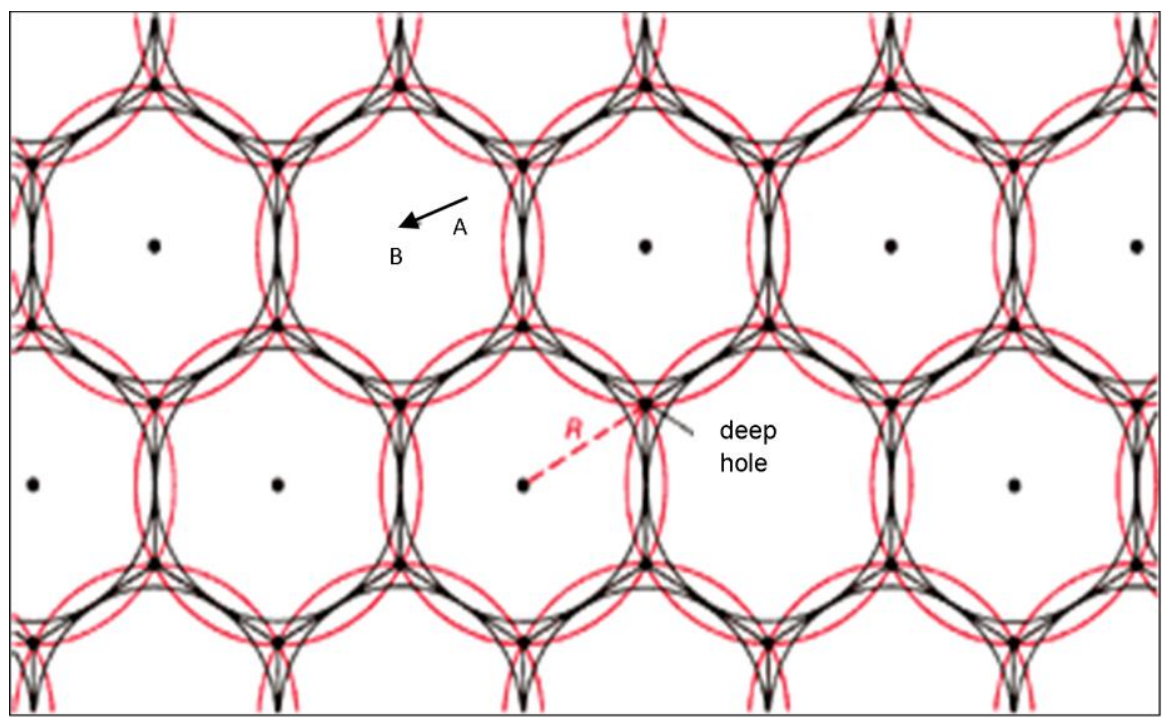

Figure 1. The sample of particle packing.

Reducing the diameter two times $(0.5 \mathrm{~cm})$ and more $(0.3 \mathrm{~cm})$, the number of particles for obtaining maximum density will increase many times. It is necessary to pay attention to the fact that hollow spaces (holes) between balls are also ball-shaped and their diameter is in harmony with the diameter of the particle. The ratio of these diameters is in compliance with the theory of fractal nested (embedded) structures.

A range of experiments with cement granules with a diameter of $0.3 ; 0.5 \mathrm{~cm}$ was conducted at the second stage of this work to find out the role of adhesive interaction. To perform these experiments, the samples consisting of cubes with the size of $5 \times 5 \times 5 \times 10^{-2} \mathrm{~m}$ were formed. Cement paste with a water-cement ratio of 0.34 was used for samples formation. Then these samples were tested for strength by their compression which lasted 1, 3, 7, 14, 28 days and 3 months. Granules of a specified size were separately formed from the cement paste of the same composition and a water-cement ratio. 
The cement concrete was obtained by mixing the cement paste with cement granules. It was established that all samples became hard under identical conditions: temperature, air and moisture.

Granules were used as fillers in the chemically similar "water-cement" system. The idea to use a filler with different time of hardening and hence with different strength, porosity and other operating characteristics was used for the first time in the technology of the cement stone production. Storage conditions of samples were identical to the storage conditions of granules. It turned out that the age of granules has a considerable effect on their cohesive strength with the cement matrix. It was also established that the higher the age of the filler is, the higher the strength of the "cement-filler-water" system. It was concluded that the age, strength and other operating characteristics of granules (filler) must be higher than for the initial cement matrix.

\section{The study of the structure of the modified lead-tin-base bronze}

The results of performed experiments are shown in Table 1. This table demonstrates the data for the cement stone obtained from Portland cement of the grade 400 (check sample) and cement stone with granules used as a filler with a diameter of $0.5 \mathrm{~cm}$ and different time of hardening.

Table 1. The characteristic of the cement stone based on the cement of the grade 400 and the cement with a filler consisting of granules which diameter is $0.5 \mathrm{~cm}$ at different time of hardening

\begin{tabular}{|c|c|c|c|}
\hline System types & Density, $(\rho), \mathrm{gr} / \mathrm{cm}^{3}$ & $\begin{array}{c}\text { Strength } \\
\text { by compression, } \\
(\mathrm{P}), \text { MPa. } \\
\text { (after } 7 \text { days of } \\
\text { hardening) }\end{array}$ & $\begin{array}{l}\text { Ratio of strength } \\
\text { to density, } \\
(\mathrm{P} / \rho), \mathbf{1 0}^{3} \mathrm{~cm}\end{array}$ \\
\hline $\begin{array}{l}\text { «Cement-water». Check } \\
\text { sample }\end{array}$ & 2.1 & 20.97 & 10.0 \\
\hline $\begin{array}{l}\text { «Cement-water-granules». The } \\
\text { time of granule hardening-- } \\
1 \text { days }\end{array}$ & 2.6 & 11.1 & 4.2 \\
\hline $\begin{array}{l}\text { «Cement-water-granules». The } \\
\text { time of granule hardening-- } \\
3 \text { days }\end{array}$ & 2.6 & 12.8 & 4.9 \\
\hline $\begin{array}{l}\text { «Cement-water-granules». The } \\
\text { time of granule hardening-- } \\
7 \text { days }\end{array}$ & 2.6 & 14.8 & 5.7 \\
\hline $\begin{array}{l}\text { «Cement-water-granules». The } \\
\text { time of granule hardening-- } \\
14 \text { days }\end{array}$ & 2.6 & 15.9 & 6.1 \\
\hline $\begin{array}{l}\text { «Cement-water-granules». The } \\
\text { time of granule hardening- } \\
28 \text { days }\end{array}$ & 2.8 & 16.4 & 5.8 \\
\hline $\begin{array}{l}\text { «Cement-water-granules». The } \\
\text { time of granule hardening-- } \\
3 \text { months }\end{array}$ & 2.9 & 20.1 & 7.2 \\
\hline
\end{tabular}

It is obvious from Table 2 that the ratio of strength to density reaches the reference values at the age of 3 months. There is a general tendency that the formation of structure is being kept by the reduction of granules diameter while the indices of structural-sensitive parameters are getting worse. 
Table 2. The characteristic of the cement stone based on the cement of the grade 400 and the cement with a filler consisting of granules which diameter is $0.5 \mathrm{~cm}$ at different time of hardening

\begin{tabular}{|c|c|c|c|}
\hline System types & $\begin{array}{c}\text { Density, }(\rho), \\
\text { gr/cm } \\
\end{array}$ & $\begin{array}{c}\text { Strength } \\
\text { by compression, } \\
(\mathrm{P}), \text { MPa. } \\
\text { (after } 28 \text { days of } \\
\text { hardening) }\end{array}$ & $\begin{array}{c}\text { Ratio of strength } \\
\text { to density, } \\
(\mathrm{P} / \rho), \mathbf{1 0}^{3} \mathrm{~cm}\end{array}$ \\
\hline «Cement-water». Check sample & 2.1 & 42.0 & 20 \\
\hline $\begin{array}{l}\text { Cement-water-granules». The time of } \\
\text { granule hardening-- } \\
1 \text { days }\end{array}$ & 2.6 & 22.5 & 8.6 \\
\hline $\begin{array}{l}\text { «Cement-water-granules». The time of } \\
\text { granule hardening- } \\
3 \text { days }\end{array}$ & 2.6 & 25.0 & 9.6 \\
\hline $\begin{array}{l}\text { «Cement-water-granules». The time of } \\
\text { granule hardening- } \\
7 \text { days }\end{array}$ & 2.6 & 30.0 & 11.5 \\
\hline $\begin{array}{l}\text { «Cement-water-granules». The time of } \\
\text { granule hardening- } \\
14 \text { days }\end{array}$ & 2.6 & 31.0 & 11.9 \\
\hline $\begin{array}{l}\text { «Cement-water-granules». The time of } \\
\text { granule hardening- } \\
28 \text { days }\end{array}$ & 2.8 & 33.0 & 11.7 \\
\hline $\begin{array}{l}\text { «Cement-water-granules». The time of } \\
\text { granule hardening- } \\
3 \text { months }\end{array}$ & 2.9 & 42.0 & 14.5 \\
\hline
\end{tabular}

The study of the effect of filler granules on the strength of the hardening structure was also of great importance. The data of the cement stone on the base of Portland cement of the grade 500 and the configuration of granules as elementary cubes with a diameter of $0.3 \mathrm{~cm}$ are presented in Table 3 .

One can see from Table 3 that the ratio of strength to density makes up 51\%. The comparison of indices of the samples produced on the basis of different cement grades (Table 2 and 3) shows the tendency of properties changes. By the increase of the particles diameter $(0.5 \mathrm{~cm}$ and greater $)$ and the change in the configuration (compared with balls), the structural characteristics are becoming worse. 
Table 3. The characteristic of the cement stone based on the cement of the grade 500 and the cement with a filler consisting of granules which diameter is $0.3 \mathrm{~cm}$ at different time of hardening

\begin{tabular}{|c|c|c|c|}
\hline System types & Density, $(\rho), \mathrm{gr} / \mathrm{cm}^{3}$ & $\begin{array}{c}\text { Strength } \\
\text { by compression, } \\
(\mathrm{P}), \mathrm{MPa} \text {. } \\
\text { (After } 28 \text { days of } \\
\text { hardening) }\end{array}$ & $\begin{array}{c}\text { Ratio of strength } \\
\text { to density, } \\
(\mathrm{P} / \mathrm{\rho}), \mathbf{1 0}^{3} \mathrm{~cm}\end{array}$ \\
\hline $\begin{array}{l}\text { «Cement-water». Check } \\
\text { sample }\end{array}$ & 2.2 & 49.6 & 22.5 \\
\hline $\begin{array}{l}\text { «Cement-water-granules». The } \\
\text { time of granule hardening- } \\
1 \text { days }\end{array}$ & 2.5 & 15.0 & 6.0 \\
\hline $\begin{array}{l}\text { "Cement-water-granules». The } \\
\text { time of granule hardening- } \\
3 \text { days }\end{array}$ & 2.7 & 17.2 & 6.3 \\
\hline $\begin{array}{l}\text { «Cement-water-granules». The } \\
\text { time of granule hardening- } \\
7 \text { days }\end{array}$ & 2.8 & 21.6 & 7.7 \\
\hline $\begin{array}{l}\text { «Cement-water-granules». The } \\
\text { time of granule hardening-- } \\
14 \text { days }\end{array}$ & 2.8 & 22.0 & 7.8 \\
\hline $\begin{array}{l}\text { «Cement-water-granules». The } \\
\text { time of granule hardening-- } \\
28 \text { days }\end{array}$ & 2.9 & 22.4 & 7.7 \\
\hline $\begin{array}{l}\text { «Cement-water-granules». The } \\
\text { time of granule hardening-- } \\
3 \text { months }\end{array}$ & 2.9 & 23.1 & 7.9 \\
\hline
\end{tabular}

\section{Conclusion}

The feature of these experiments is in forming a "cement granular- cement stone" contact area, where the strength behavior on the boundary is purely cohesive in terms of chemical bonds. However, experiments showed that the difference in age, strength and other sensitive characteristics of the cement stone and cement granules leads to the transformation of the part of cohesive contacts in a mixed substance in a form of cohesive-adhesive accretion contact. These data allow us to state that studies concerning adhesion, classification of adhesion and cohesion forces, the nature of their interaction require some updating and development. Their interaction is a complicated and hierarchical process. Fibonacci numbers serve as indicators by formation of these structures provided that maximum density is reached, since the ratio of particles size and their content in a system correlate as harmonic numbers [18].

\section{References}

[1] Demyanenko O V, Kopanitsa N O, Sarkisov Yu S, Abzaev Y A, Ikonnikova K V \& Ikonnikova L F 2017 Quantitative phase analysis of modified hardened cement paste IOP Conference Series: Earth and Environmental Science 87(9) 092008 DOI: 10.1088/1755-1315/87/9/092008

[2] Stewart A, Scholsser B, Douglas E P 2013 Surface modification of cured cement pastes by silane coupling agents Journal of Applied Materials and Interfaces 5(4) 1218-1225

[3] Djouani F, Connan C, Delamar M, Chehimi M M, Benzarti K 2011 Cement paste-epoxy adhesive interactions Construction and Building Materials 25 411-423 
[4] Blackburn B P, Tatar J, Douglas E P, Hamilton H R 2015 Effects of Hygrothermal Conditioning on Epoxy Adhesives Used in FRP Composites Construction and Building Materials, 96C 679689

[5] Dvorkin L, Dvorkin O, Garnitsky Y, Ribakov Y 2014 Adhesive and cohesive properties of glue cement mortars with addition of organic-mineral modifiers Materials and Design 53 588-595

[6] Uchikawa H 1986 Effect of blending components of hydration and structure formation In: 8th International congress of the chemistry of the cement VI Rio de Janeiro 250-280

[7] Erdog du K, Turker P 1998 Effects of fly ash particle size on strength of Portland cement fly ash mortars Cem. Concr. Res. 28 (9) 1217-1222

[8] Philosophy of science 2001 The formation of modern natural-science paradigm M.: 7

[9] Shelepin L A 2001 The formation of new paradigm in natural science Philosophy of science M.: $723-42$

[10] Ikonnikova K, Ikonnikova L, Koltunova E 2016 Research of electro-explosive iron powder using the hydrolytic adsorption method AIP Conference Proceedings 1772020010

[11] Ikonnikova K, Ikonnikova L, Koltunova E 2015 Turkish Online Journal of Educational Technology 485-488

[12] Stakhov A P 2009 The Mathematics of Harmony From Euclid to Contemporary Mathematics and Computer Science World Scientific 73

[13] Korobko V I, Korobko G N 1995 The fundamentals of structural harmony of natural and artificial systems Stavropol 350

[14] Smirnov B M 1991 Hysics of fractal clusters M.: Science. Chief editorial board-mathematical literature (modern problems in Physics) ISBN 5-02-014629-3 136

[15] Pietronero L, Tosatti E 1986 Fractals in Physics Amsterdam: North Holland, Translated from English M.: Mir 1988672

[16] Kharkhadin A N 2008 Fractal regularity of dispersed systems Bulletin of Universities Construction 8 102-107

[17] Sloan N J A 1984 The packing of spheres Scientific American 250116 - 125 doi:10.1038/scientificamerican0 184-116

[18] Vladimirov V L 2010 Fibonacci and Luke series and the degree of golden constant - particular case of diffusive recursion relations Report at International Conference in Mathematics, Harmonics. Odessa www. Goldensectionclub.net/home/congress/speeches 